\title{
アルドステロンによる心血管系臟器障害のメカニズム
}

\author{
長田太助, ${ }^{*}$ 平田恭信
}

\section{Molecular Mechanism of Cardiovascular Damage Induced by Aldosterone}

\author{
Daisuke NAGATA* and Yasunobu HiRATA \\ Cardiovascular Medicine, Graduate School of Medicine, University of Tokyo, \\ 7-3-1 Hongo, Bunkyo-ku, Tokyo 113-8655, Japan
}

(Received May 21, 2007)

\begin{abstract}
Although the pro-inflammatory and pro-fibrotic actions of aldosterone on the vasculature have been reported, the effects and molecular mechanisms of aldosterone on endothelial function are yet to be determined. We investigated how aldosterone regulates endothelial nitric oxide synthase (eNOS) function in human umbilical vein endothelial cells (HUVECs). HUVECs were incubated for $16 \mathrm{hrs}$ with $10^{-7} \mathrm{~mol} / 1$ of aldosterone. The concentration of reactive oxygen species (ROS) was estimated by measuring DCF chemiluminescence. Signal transduction was estimated by Western immunoblots. Realtime RT-PCR was performed to measure expression of transcripts of endogenous GTP cyclohydrolase$1(\mathrm{GCH} 1)$ and components of NAD $(\mathrm{P}) \mathrm{H}$ oxidase. In order to eliminate the possible effect of the glucocorticoid receptor (GR), and to emphasize the role of mineralocorticoid receptor (MR), we used GR siRNA and knocked down GR expression in several experiments. NO output was estimated by intracellular cGMP concentration. ROS production increased significantly in aldosterone-treated HUVEC, but was abolished by pre-treatment with eplerenone. Transcripts of p47 ${ }^{\text {phox }}$ were increased by aldosterone treatment. Vascular endothelial growth factor (VEGF)-induced eNOS Ser 1177 but not Akt Ser 473 phosphorylation levels were reduced significantly by pretreatment with aldosterone. Pretreatment with either eplerenone or okadaic acid restored phosphorylation levels of eNOS Ser 1177 in aldosterone-treated cells, suggesting that protein phosphatase (PP) 2A was upregulated by aldosterone via MR. The decrease in NO output caused by aldosterone pretreatment was reversed significantly by either 5,6,7,8-tetrahydrobiopterin $\left(\mathrm{BH}_{4}\right), \mathrm{GCH}_{1}$ overexpression, or $\mathrm{p} 47^{\text {phox }}$ knockdown. These results suggest that aldosterone inhibits eNOS function through bimodal mechanisms of $\mathrm{BH}_{4}$ deficiency and $\mathrm{PP} 2 \mathrm{~A}$ activation.
\end{abstract}

Key words_ aldosterone; reactive oxygen species; endothelial nitric oxide synthase; mineralocorticoid receptor

\section{1. はじめに}

アルドステロン (Aldo) の主な作用は，腎臓尿 細管上皮や腸管粘膜上皮のナトリウム再吸収を介し た循環血漿量の増加による血圧上昇と考えられてき た.しかし最近 Aldoの上皮系組織への作用を介さ ない心血管系への障害作用が明らかになってきた。

ここでは，副腎皮質におけるAldo の自律性産生に より生じる内分泌性高血圧である primary aldosteronism (PA) と臓器障害の関連と, Aldo の直 接的心血管系障害の分子機序について概説したい.

東京大学大学院医学系研究科循環器内科学（T1138655 東京都文京区本郷 7-3-1)

*e-mail: dskngtendo0504-tky@umin.net

本総説は, 日本薬学会第 127 年会シンポジウムS19 で 発表したものを中心に記述したものである.

\section{Primary Aldosteronism の病態}

世界で最初にPA の患者を報告した Conn は， PA は高血圧患者の $20 \%$ 程度を占めるかなり major な疾患であると予想していたが，次第に下方修正さ れ，比較的最近まで $1 \%$ 未満の稀な疾患と考えられ てきた。しかし，ホルモンの測定，画像診断の日常 化とともに，血漿 Aldo 濃度（PAC: $\mathrm{ng} / \mathrm{dl}$ ） と血漿 レニン活性（PRA: $\mathrm{ng} / \mathrm{ml} / \mathrm{hr}$ ) の比（Aldo・レニ ン比 $\mathrm{ARR}=\mathrm{PAC} / \mathrm{PRA} ）$ がスクリーニングで用い られるようになってから，本態性高血圧症（Essential Hypertension; EH）と考えられていた症例の中 にPA と診断される患者が多くなってきた. Fardella ら1)は, EH と診断された患者のうち約 $10 \%$ が PA であり，高血圧の重症度が上がるほど PA と診断さ れる率が上昇すると報告している。極めて稀な二次 性高血圧症と考えられてきたPA は，実は当初 
Conn らが予想していた数字に近い頻度の疾患であ る可能性がある.

拾い上げられる PA 症例が増えるほど血清カリウ 厶正常，Aldo 増加が軽度-正常，レ二ン抑制が弱い, CT スキャン画像において腫瘍を認めないなど, EH 若しくはメタボリック症候群に分類されかねな い症例が増加してきた。非典型的 PA に，最近本邦 でも増加している肥満や耐糖能障害・脂質代謝異常 が偶然合併していた場合にはメタボリック症候群と 全く区別ができない場合が多いからである，低レニ ン性で予後がよいと考えられてきた ${ }^{2)} \mathrm{PA}$ の患者に は後述のように心血管系の合併症が多く報告されて おり，しっかりとした病態の見極めが患者の予後に 影響する可能性がある.

\section{3. アルドステロンの臟器障害作用}

Aldoの相対的過剩状態と心血管系合併症との関 連が知られており，割合早期からそれに関する報告 がある. ${ }^{3)}$ 本邦でも脳出血が本態性高血圧に比べ有 意に多いことが報告されている. ${ }^{4)}$ 腎臟に関しては 西山らの項において詳細に解説されているので，こ こではその他の臓器について概説したい.

3-1. Aldo と脸障害 Mineralocorticoid receptor（MR）をブロックした際，心血管事故と同様に 脳血管事故は減少するとの報告が散見される一方，

Aldo は脳梗塞後の海馬における神経細胞死を抑制 する働きも報告されており，脳血管障害においては 善玉なのか悪玉なのか，はっきりしないところがあ る. ${ }^{5)} \mathrm{PA} と \mathrm{EH}$ を比較した最近の臨床の報告6)で は，脳卒中（出血・梗塞両方を含む）の発症率が PA で EH に比べ有意に高いとされている。 また， 脳卒中易発症高血圧自然発症ラット（SHRSP）を 使った動物実験では，スピロノラクトン投与が梗塞 サイズを有意に減少させており,7) 今後さらに詳細 な検討が必要であろう。

\section{3-2. Aldo と心血管系障害 血漿 Aldo 濃度が} かならずしも高值ではない病態においても，心臓で は Aldoが障害性に作用することは，大規模臨床試 験 Randomized Aldactone Evaluation Study (RALES) や Eplerenone Post-AMI Heart Failure Efficacy and Survival Study（EPHESUS）において，スタンダー ドなアンジオテンシン変換酵素（ACE）阻害薬や $\beta$ - 遮断薬による治療との併用で非降圧量の MR 阻 害薬併用が心不全患者の生命予後を著明に改善した
ことからも支持される(Fig. 1). ${ }^{8,9)}$ Tanabe ら ${ }^{10)}$ は, PA 患者 164 例の検討で約 50\%に心，腎，血管合併 症の少なくともいずれかを認め，特に心肥大の頻度 が最も高く, 脳血管障害も認めた。 また心エコー所 見を EH, Cushing 症候群, 褐色細胞腫の患者と比 較したところ，PA での心肥大の頻度と程度が最も 高く，予後の悪い求心性肥大が主であった。これら の結果は Aldo が高血圧を介する間接作用に加え て，直接作用により臓器障害を招来することを示唆 している.

\section{4. アルドステロンの臓器障害の分子機序}

Aldo の心臓など非上皮性組織への直接作用があ ることは，早期から Weber ら ${ }^{11)}$ が精力的に報告し いる. Dzau ら ${ }^{12)}$ は, 循環調節ホルモンとしてのレ ニン・アンジオテンシン（RA）系だけではなく， 心血管組織にレニンや ACE が存在しアンジオテン シンII（AngII）を産生し得ることを証明し，局所 で働く RA 系の存在を示した，その後，Aldo 合成 酵素も血管や心臟局所に存在することが証明さ れ, 4,13) Aldo 産生系はセットで心血管系局所に存在 することが明らかになった。一方，心血管系には MR と，腎臓や結腸に比べると少量だが Aldoの $\mathrm{MR} へ$ の結合の特異性を確保する $11 \beta$-hydroxysteroid dehydrogenase type2 (11 $\beta$-HSD2) が発現し ていることが示されている. ${ }^{14)}$

最近, AngII が AngII タイプ 1 (AT1) レセプター を介して Aldo の合成を促すという単純な図式では 説明できない現象が多々報告されている。 Ullian ら ${ }^{15)}$ は血管平滑筋では Aldo 刺激がAT1 レセプ ターを誘導することを以前に示したが，その後 Harada ら ${ }^{16)}$ が新生児ラット心筋細胞で，また Sugiyama ら ${ }^{17)}$ はラット血管内皮細胞で Aldo 刺激 により ACE の発現が増加し，MR 拮抗薬がそれを 抑制することを示した。 また Aldo は血管系におい てアンジオテンシノーゲン産生充進を介して AngII を増加させ，虚血下肢における血管新生を亢進させ

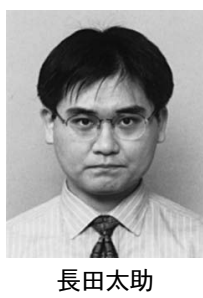

東京大学医学部助教. 1992 年東京大学 医学部医学科卒業. 2000 年同大学院医 学系研究科修了. 医学博士. 2000-2003 年ボストン大学心血管研究所に留学. 2004-2006 年国立京都病院研究室長. 2006 年 5 月より現職。基礎・臨床両面 からのアプローチにより血管内皮障害 の効果的予防法を開発することが目標. 


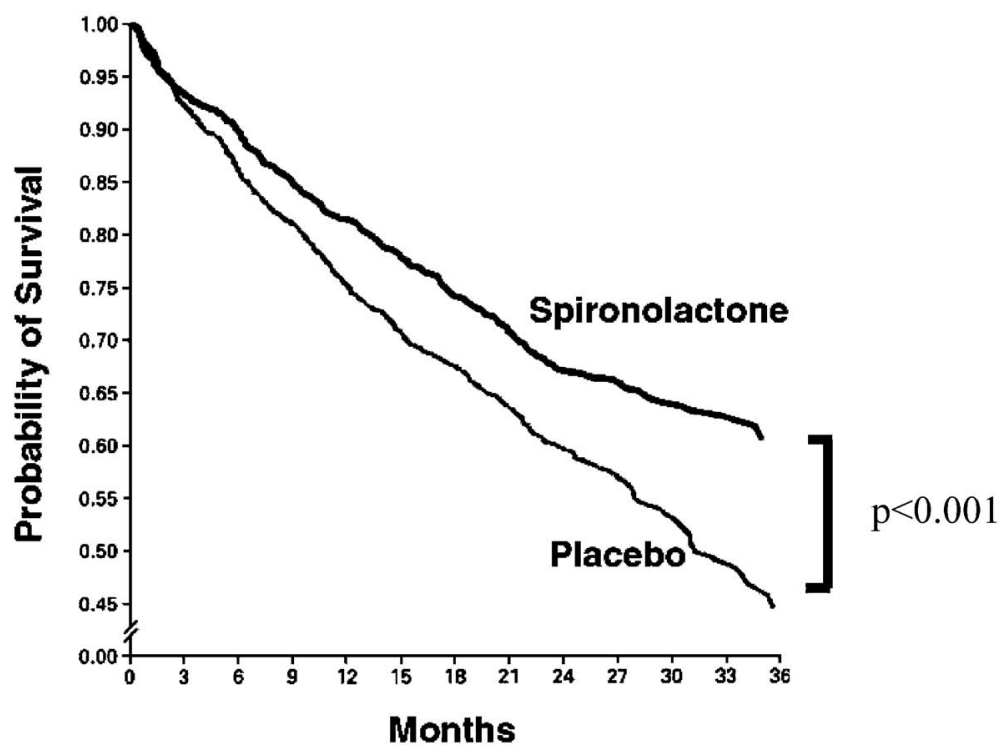

Fig. 1. Spironolactone Significantly Improved Mortality of Heart Failure Patients Taking ACE Inhibitor or Conventional Medication

(Modified from Ref. 8).

るという報告もあり, ${ }^{18)}$ 今後適切な薬剤による治療 的介入の戦略を打ち立てる上で RA・Aldo 系構成 要素間の調節機構をさらに明らかにしていく必要が ある。

4-1. 血管内皮障害血管内皮細胞における Aldo の内皮型一酸化窒素合成酵素（eNOS）への作 用は未解決な点が多い. Aldo は NO の産生を抑制 するという報告 ${ }^{19,20)}$ と，逆に産生を促して血管を拡 張すると主張する正反対の報告 ${ }^{14,21)}$ がある。しかし 後者の 2 報告はいずれも数分-数十分の短い刺激時 間での結果をみており，しかも両者が phosphoinositide 3-kinase（PI3K） を介していることか ら，恐らくMR を介さない non-genomic 作用であ り，Aldo の長時間刺激による genomic な作用に基 づく血管障害とは区別しなければならない，短期的 には non-genomic に eNOS が活性化され NO 産生 が増えるかも知れないが，Aldo の内皮機能障害の 一部は genomic 作用を介した eNOS 活性抑制によ ると考えた方に整合性があるとわれわれは考えてい た。そこでわれわれは, ${ }^{22)}$ Aldo によって eNOS の NO 産生能が低下するのかを in vitro の実験系で確 かめた. Aldo $10^{-7} \mathrm{~mol} / 116$ 時間刺激後, vascular endothelial growth factor (VEGF) で刺激したのち の NO 産生を cGMP 濃度にて評価したところ, Aldo 処置により NO 産生は減少した。この NO 産 生減少は，MR 阻害薬であるエプレレノンで有意に

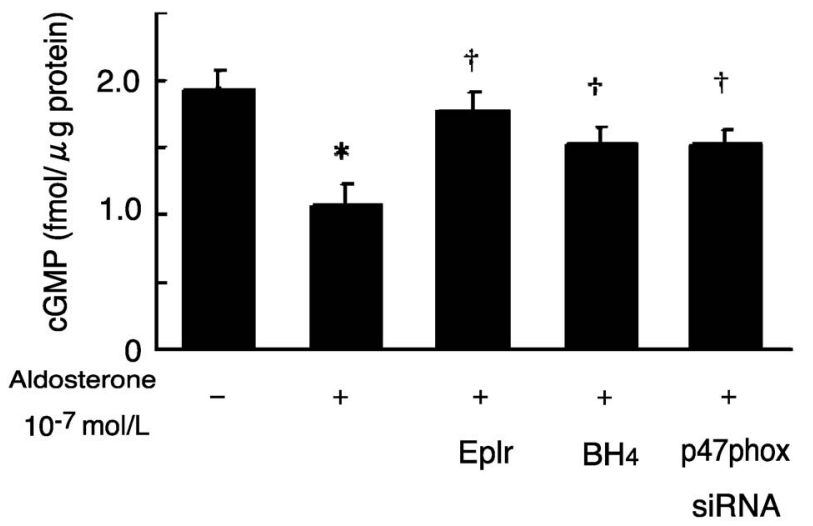

Fig. 2. NO Production from HUVECs Increased when Stimulated by VEGF, but Pretreatment with Aldo Significantly Inhibited This Effect

Eplerenone (Eplr), tetrahydrobiopterin $\left(\mathrm{BH}_{4}\right)$, or $\mathrm{p} 47^{\text {phox }}$ knock down by siRNA reversed aldosterone-induced inhibition of NO production from HUVECs. ${ }^{*} p<0.01$ vs Aldo,$-{ }^{*} p<0.05$ vs Aldo + .

回復した。また，p47phox の siRNA によるノックダ ウン, さらには eNOS の co-factor であるテトラヒ ドロバイオプテリン $\left(\mathrm{BH}_{4}\right)$ でも $\mathrm{NO}$ 産生減少は部 分的ではあるが有意に回復した（Fig. 2)。リン酸 化により eNOS の活性を上げるとされる Ser1177 を みてみると, VEGF で確かにリン酸化の程度が増 えたが，Aldoで処置しておいた細胞ではそれが抑 制された（Fig. 3)。MR 阻害薬やオカダ酸（protein phosphatase (PP) 2A 阻害薬) の前処置ではそ の抑制が解除された。NO 産生に関しては抑制的に 


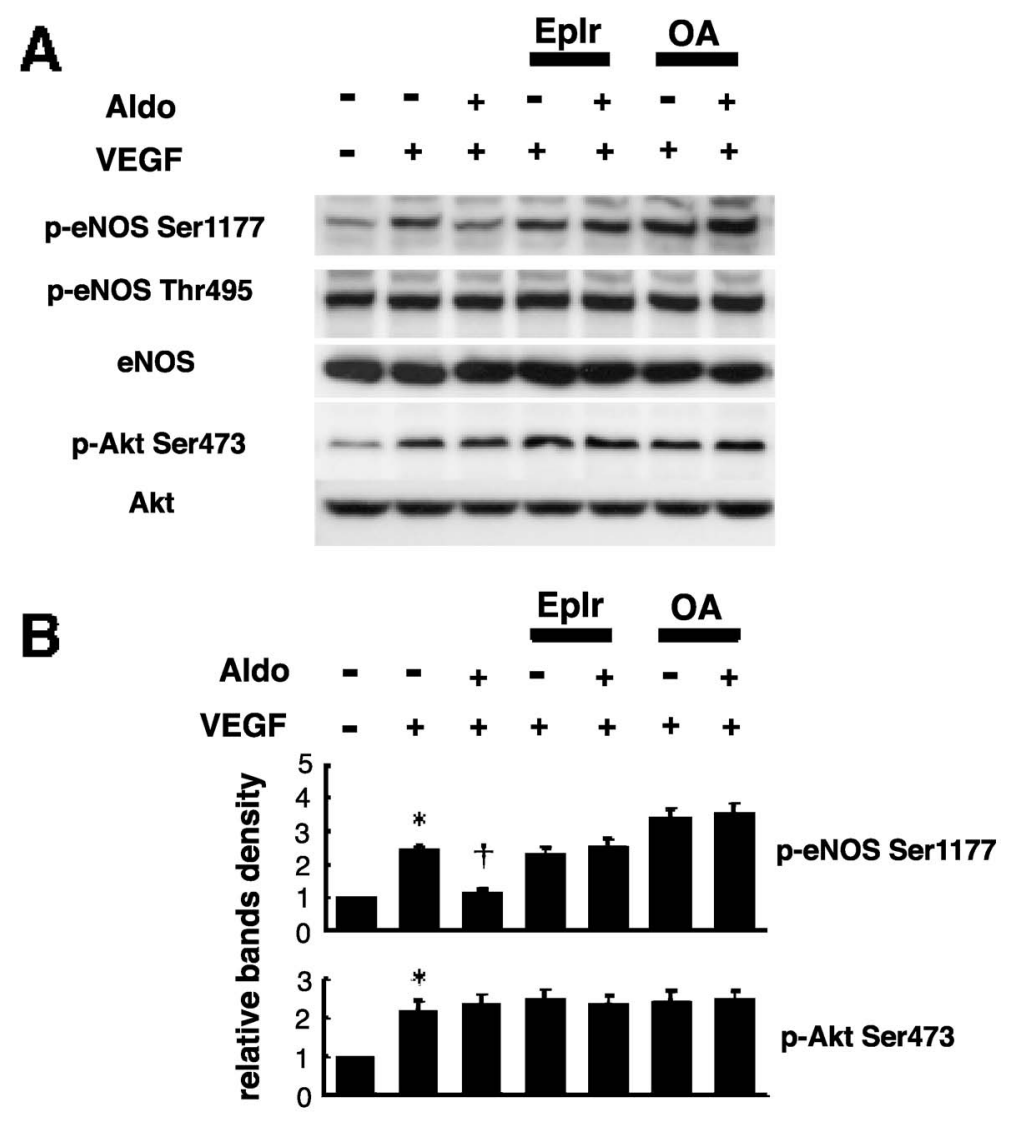

Fig. 3. A) Aldosterone Downregulated eNOS Ser1177 Phosphorylation, but did not Alter Akt Ser473 Phosphorylation Levels, B) The Statistical Analyses of 4 Independent Experiments of (A) are Shown

Eplerenone or okadaic acid significantly reversed the inhibitory effect of aldosterone on eNOS Ser1177 phosphorylation. Each bar represents the mean \pm S.E., ${ }^{*} p<0.01$ vs Aldo $-/$ VEGF,$-{ }^{t} p<0.01$ vs Aldo - VEGF +. VEGF: VEGF $100 \mathrm{ng} / \mathrm{ml}$, Eplr: Eplerenone $10^{-5} \mathrm{~mol} / \mathrm{l}, \mathrm{OA}:$ okadaic acid $10^{-8} \mathrm{~mol} / 1$.

働く Thr495 での eNOS リン酸化については変化が なかった。 さらに上位キナーゼである Akt をみた ところ, VEGF 刺激下では各群で差がみられない ことから，PP2A 活性化による eNOS Ser1177 脱リ ン酸化が eNOS 活性低下の機序として重要である ことが明らかになった（Fig. 3). 今回われわれが 明らかにした点と他の研究者の報告とをまとめると Fig. 4 のようになる.

後述するように, 内皮障害には NAD (P)H oxidase による活性酸素種（ROS）産生が重要な働き をしていると考えられるが，高血糖も ROS の産生 を介して血管内皮障害を惹起せしめることから，

Aldo がその作用を増強する可能性は十分考えら れ，耐糖能障害とAldo が連係して血管内皮障害の 程度を強くしているのかもしれない.

4-2. 血管周囲の炎症 · 線維化 最近になって 線維化に先立つ炎症性変化とその誘因の 1 つである $\operatorname{ROS}$ の産生機序について分子機序が少しずつ明ら
かになってきた. Aldo は AngII 同様, NAD (P)H oxidase のコンポーネントである p22 phox, Nox-4, gp91 phox などを誘導することによって ROS 産生を 増加させると考えられる. ${ }^{23-25)}$ Sun ら ${ }^{25)}$ は, Aldo と高食塩負荷を 4-5 週間維持したラット心臓では, 血管やその周囲において gp91 ${ }^{\text {phox }}$ と 3-nitrotyrosine が増加しており， NF- $\kappa \mathrm{B}$ も活性化されていること を免疫組織学的に示した。 また同じ部位で monocyte chemoattractant protein-1 (MCP-1), intercellular adhension molecule-1 (ICAM-1), tumor necrosis factor (TNF) - $\alpha$ など炎症を促進する分子群の発現 も充進しており, マクロファージの浸潤や血管平滑 筋の増殖もみられたが, これらの変化はスピロノラ クトンや抗酸化剂の pyrrolidine dithiocarbamate (PDTC) や N-acetyl cysteine（NAC）により減弱 していた（Fig. 5)。これらの結果は, より選択的 な MR 阻害薬であるエプレレノンを使った Rocha ら26)の結果とほぼ一致している，彼らも炎症細胞の 


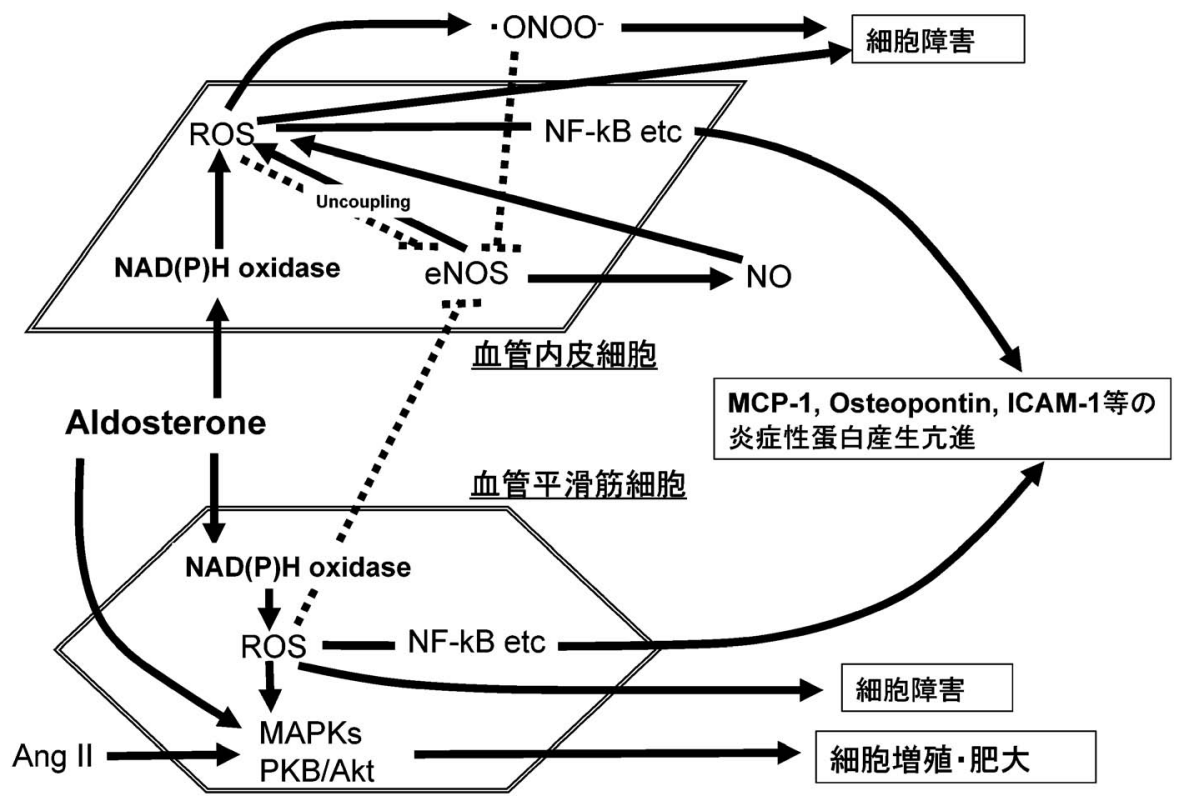

Fig. 4. Aldo Increases Oxidative Stress in Both Vascular Endothelial Cells and Smooth Muscule Cells

Aldo also activates NF- $\kappa$ B signaling and induces some inflammatory proteins transcription. Solid lines: activation, Dotted lines: inhibition.

A

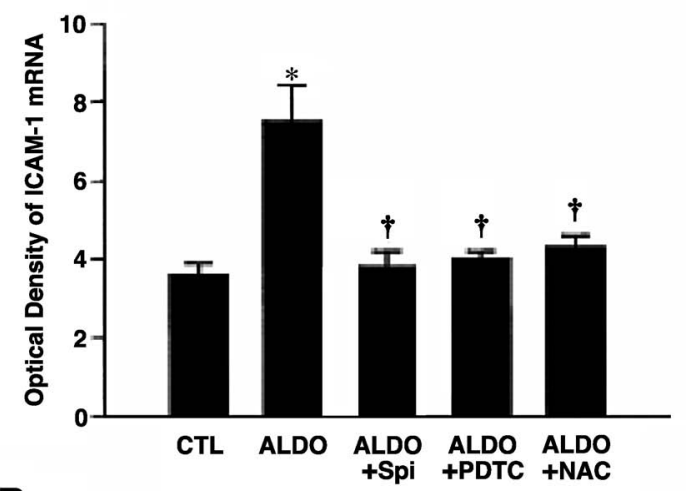

B

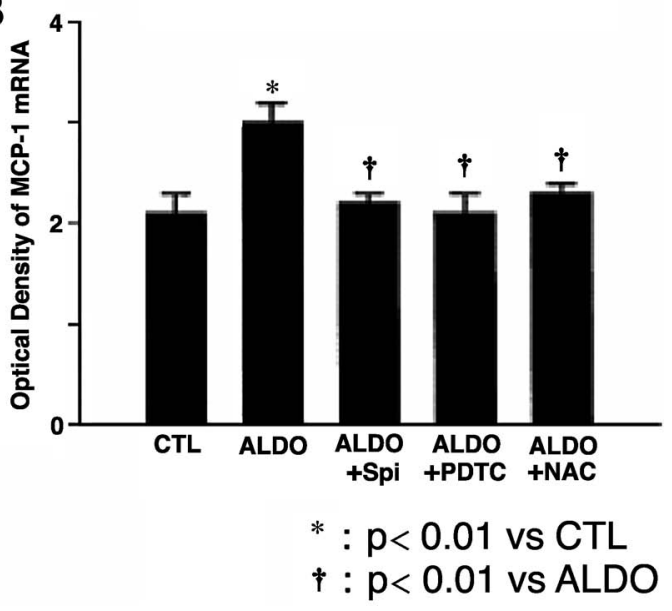

Fig. 5. Aldosterone-induced Transcriptional Up-regulation of ICAM-1 or MCP-1 was Inhibited by Spironolactone (Spi), PDTC, or NAC

(Modified from Ref. 25).
浸潤などに先立って cyclooxygenase-2，MCP-1, ICAM-1，osteopontin などの発現が主に心臓の血管 で増えており，その発現はエプレレノンで有意に抑 制されたと報告している．Schiffrin ら27)は，血管に おいて AngII で誘導される内皮機能障害・血管リ モデリングなぞ一連の反応がスピロノラクトン投与 により減弱することを示しているが，ヒドララジン により血圧を下げても同様の効果はみられないこと, NAD (P)H oxidase の活性化がスピロノラクトンで 抑制されることなどから，AngII による血管障害の 一部は Aldo を介していると推測している。 また興 味深いことに Rajagopalan ら ${ }^{20)}$ はニュージーランド ウサギに 6 週間高コレステロール食を与えると大動 脈の NAD $(\mathrm{P}) \mathrm{H}$ oxidase 活性が有意に上昇するが, エプレレノン投与でそれが基礎值レベルまで低下し 得ることを示した（Fig. 6）。また内皮依存性の血 管拡張反応もエプレレノンで有意に改善したことか ら, 動脈硬化の初期変化が Aldo の阻害にて改善さ れる可能性を示した.

また Aldo は plasminogen activator inhibitor-1の 産生を促進しており，血栓形成を促す可能性を指摘 する報告もあるので, ${ }^{28)}$ この点でも MR 阻害の利点 があると思われる.

4-3. アルドステロン・ブレイクスルー＼cjkstart高血 圧治療に汎用されている ACE 阻害薬やある種の 
AT1 受容体拮抗薬（ARB）を長期に使用した場合， 投与初期には低下した Aldo の血中濃度が再上昇す ることがある。この現象をアルドステロン・ブレイ クスルー（aldosterone breakthrough）と呼んでい る。 ACE 阻害薬や ARBによって抑えきれない臓

A

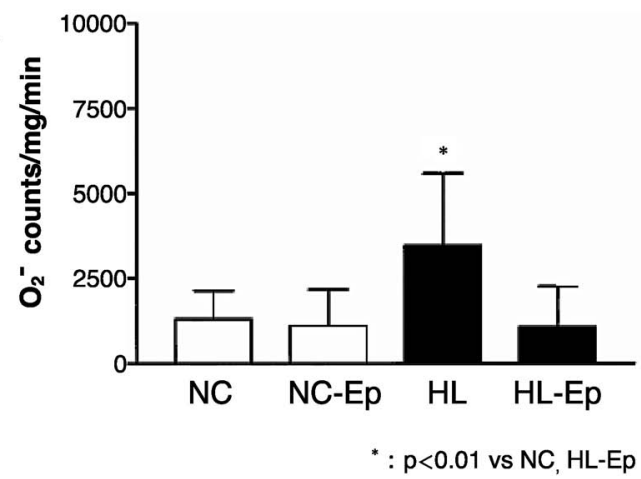

B

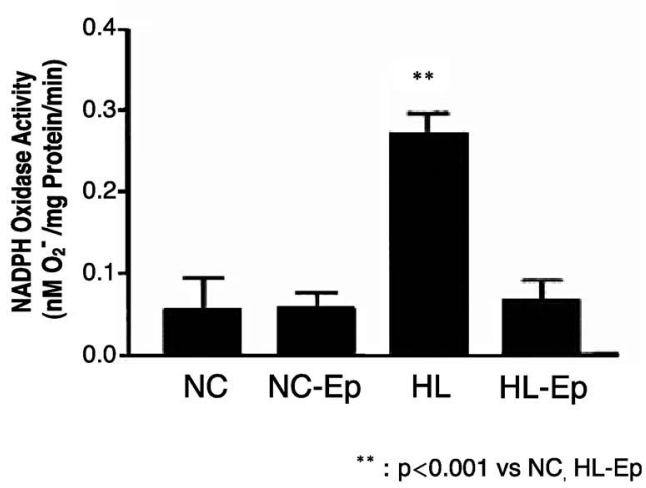

Fig. 6. Both ROS Production and NADPH Oxidase Activity in Rabbit Aorta Increased in High Cholesterol Chow Group

(HL) Compared to Normal Chow Group (NC)

Eplerenone (Ep) significantly inhibited these effects. (Modified from Ref. 20).
器障害の一部は，この現象を介している可能性も指 摘されている. ${ }^{29)}$ それゆえ低用量の Aldo 拮抗薬併 用の有用性が予想される。動物実験では SHR に長 期間 ARB を投与したのちの PAC の再上昇はデキ サメサゾンでも部分的に抑制されたが, AngII タイ プ 2 (AT2) 受容体拮抗薬である PD123319 でさら

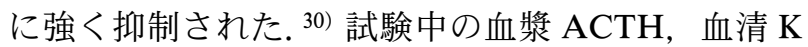
濃度は変化しなかったことから，上昇した AngII がAT2 レセプターを介した Aldo 産生増加が PAC 再上昇の主な原因であると推測された。 また同じ高 血圧ラットで ARB 単独, スピロノラクトン単独, $\mathrm{ARB}+$ スピロノラクトン併用の心保護作用を比べ たところ，併用群では単独群よりも有意に I 型, III 型コラーゲン mRNA が抑制され，間質・血管 周囲の線維化が減少していた. ${ }^{31)}$ 今後の大規模臨床 試験で, ACE 阻害薬あるいは ARB と少量の Aldo 阻害薬の組み合わせの臓器保護効果がヒトでも明ら かになることが期待される。

5. おわりに一今後の見通し一

発見から50 年もの歴史があるにも係わらず, Aldo の研究は, カスケード上その 1 つ上流である AngII に比してかなり遅れている。その理由を考え てみると, MR にはAldoよりも体内に豊富に存在 する糖質コルチコイド（ヒトではコルチゾール）が 多く結合しており，Aldoの作用をマスクしている こと, 逆にAldo は glucocorticoid receptor にも結 合することができ，単純にこれは MR を介してい ると言うのが難しいことなどが上げられよう。

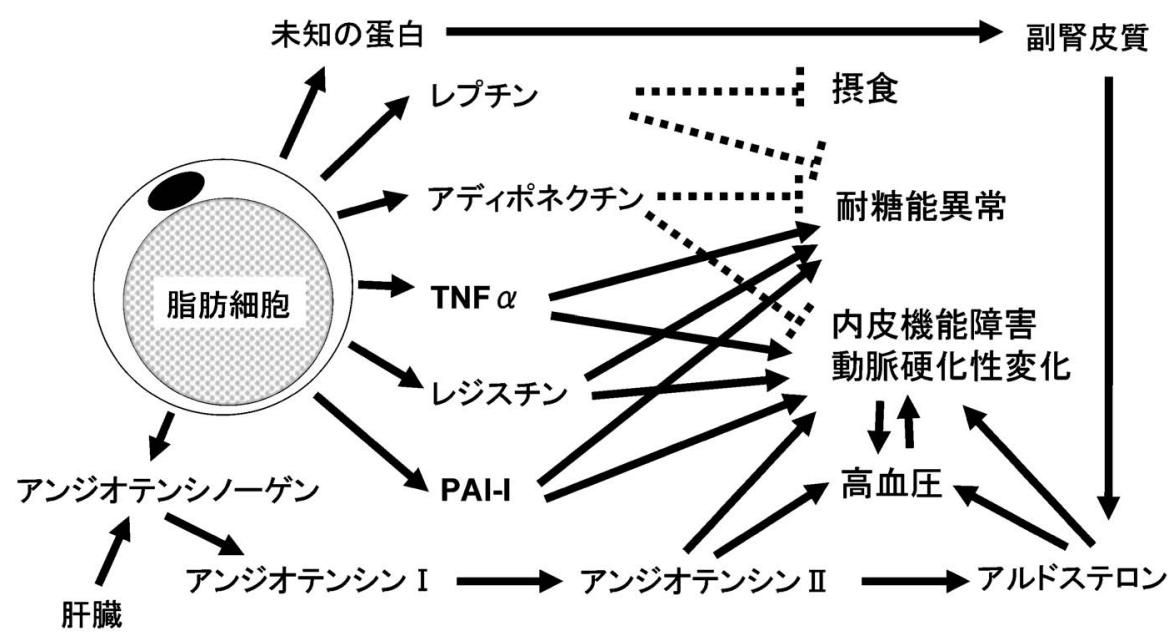

Fig. 7. Adipocytes have Known to Secrete Various Kind of Cytokines (Adipo cytokines, adipokines) Recently some unidentified proteins were shown to increase Aldo secretion from adrenal glands. Solid lines: activation, Dotted lines: inhibition. 
Kitagawa ら ${ }^{32)}$ は，MR に Aldo が結合したときと hydrocortisone が結合したときでは転写開始のため の coactivator complex との結合が異なることを示 し，Aldo が MR に結合することの特異性を部分的 に証明した。 今後これを手掛かりにして次々と新知 見が集積していくことが望まれる．また，ヒトの脂 肪細胞から分泌される AngII や既存のアディポサ イトカインでもない未知の蛋白が副腎系の培養細胞 での Aldo 産生を促進するという興味深い報告が注 目されている (Fig. 7). 33) 今後はメタボリックシン ドロームの高血圧の発症機序に Aldo がどの程度関 与しているかなどが明らかになってくることが期待 される.

最近われわれは，11/-HSD2 を血管平滑筋特異的 に発現させるトランスジェニックマウスを開発し， 現在解析中である. Aldo の血管局所での作用（特 に血管平滑筋からの活性酸素種産生六進とそれによ る障害作用）について，今後詳細に検討を進める予 定である.

\section{REFERENCES}

1) Fardella C. E., Mosso L., Gomez-Sanchez C., Cortes P., Soto J., Gomez L., Pinto M., Huete A., Oestreicher E., Foradori A., Montero J., J. Clin. Endocrinol. Metab., 85, 18631867 (2000).

2) Laragh J. H., Ulick S., Januszewicz V., Deming Q. B., Kelly W. G., Lieberman S., J. Clin. Invest., 39, 1091-1106 (1960).

3) Beevers D. G., Brown J. J., Ferriss J. B., Fraser R., Lever A. F., Robertson J. I., Tree M. Q., J. Med., 45, 401-410 (1976).

4) Takeda R., Matsubara T., Miyamori I., Hatakeyama H., Morise T., J. Endocrinol. Invest., 18, 370-373 (1995).

5) Rigsby C. S., Cannady W. E., Dorrance A. M., Trends Endocrinol. Metab., 16, 401-406 (2005)

6) Milliez P., Girerd X., Plouin P. F., Blacher J., Safar M. E., Mourad J. J., J. Am. Coll. Cardiol., 45, 1243-1248 (2005).

7) Dorrance A. M., Osborn H. L., Grekin R., Webb R. C., Am. J. Physiol. Regul. Integr. Comp. Physiol., 281, R944-950 (2001).

8) Pitt B., Zannad F., Remme W. J., Cody R., Castaigne A., Perez A., Palensky J., Wittes
J., N. Engl. J. Med., 341, 709-717 (1999) .

9) Pitt B., Remme W., Zannad F., Neaton J., Martinez F., Roniker B., Bittman R., Hurley S., Kleiman J., Gatlin M., N. Engl. J. Med., 348, 1309-1321 (2003).

10) Tanabe A., Naruse M., Naruse K., Hase M., Yoshimoto T., Tanaka M., Seki T., Demura R., Demura H., Hypertens. Res., 20, 85-90 (1997) .

11） Brilla C. G., Pick R., Tan L. B., Janicki J. S., Weber K. T., Circ. Res., 67, 1355-1364 (1990)

12) Dzau V. J., Circulation, 77, I4-13 (1988).

13) Silvestre J. S., Robert V., Heymes C., Aupetit-Faisant B., Mouas C., Moalic J. M., Swynghedauw B., Delcayre C., J. Biol. Chem., 273, 4883-4891 (1998).

14) Uhrenholt T. R., Schjerning J., Hansen P. B., Norregaard R., Jensen B. L., Sorensen G. L., Skott O., Circ. Res., 93, 1258-1266 (2003) .

15) Ullian M. E., Hutchison F. N., Hazen-Martin D. J., Morinelli T. A., Am. J. Physiol., 264, C1525-1531 (1993).

16) Harada E., Yoshimura M., Yasue H., Nakagawa O., Nakagawa M., Harada M., Mizuno Y., Nakayama M., Shimasaki Y., Ito T., Nakamura S., Kuwahara K., Saito Y., Nakao K., Ogawa H., Circulation, 104, 137139 (2001).

17) Sugiyama T., Yoshimoto T., Tsuchiya K., Gochou N., Hirono Y., Tateno T., Fukai N., Shichiri M., Hirata Y., Endocrinology, 146, 3900-3906 (2005).

18) Michel F., Ambroisine M. L., Duriez M., Delcayre C., Levy B. I., Silvestre J. S., Circulation, 109, 1933-1937 (2004).

19) Farquharson C. A., Struthers A. D., Circulation, 101, 594-597 (2000).

20) Rajagopalan S., Duquaine D., King S., Pitt B., Patel P., Circulation, 105, 2212-2216 (2002)

21） Liu S. L., Schmuck S., Chorazcyzewski J. Z., Gros R., Feldman R. D., Circulation, 108, 2400-2406 (2003).

22) Nagata D., Takahashi M., Sawai K., Tagami T., Usui T., Shimatsu A., Hirata Y., Naruse M., Hypertension, 48, 165-171 (2006) .

23) Nishiyama A., Yao L., Nagai Y., Miyata K., Yoshizumi M., Kagami S., Kondo S., 
Kiyomoto H., Shokoji T., Kimura S., Kohno M., Abe Y., Hypertension, 43, 841-848 (2004).

24) Park Y. M., Park M. Y., Suh Y. L., Park J. B., Biochem. Biophys. Res. Commun., 313, 812-817 (2004).

25) Sun Y., Zhang J., Lu L., Chen S. S., Quinn M. T., Weber K. T., Am. J. Pathol., 161, 17731781 (2002).

26) Rocha R., Funder J. W., Ann. N. Y. Acad. Sci., 970, 89-100 (2002).

27) Virdis A., Neves M. F., Amiri F., Viel E., Touyz R. M., Schiffrin E. L., Hypertension, 40, 504-510 (2002).

28) Sawathiparnich P., Kumar S., Vaughan D. E., Brown N. J., J. Clin. Endocrinol. Metab., 87, 448-452 (2002).

29) Sato A., Saruta T., Am. J. Hypertens., 16,
781-788 (2003).

30) Naruse M., Tanabe A., Sato A., Takagi S., Tsuchiya K., Imaki T., Takano K., Hypertension, 40, 28-33 (2002).

31) Tanabe A., Naruse M., Hara Y., Sato A., Tsuchiya K., Nishikawa T., Imaki T., Takano K., J. Hypertens., 22, 1017-1023 (2004) .

32) Kitagawa H., Yanagisawa J., Fuse H., Ogawa S., Yogiashi Y., Okuno A., Nagasawa H., Nakajima T., Matsumoto T., Kato S., Mol. Cell. Biol., 22, 3698-3706 (2002).

33) Ehrhart-Bornstein M., Lamounier-Zepter V., Schraven A., Langenbach J., Willenberg $\mathrm{H}$. S., Barthel A., Hauner H., McCann S. M., Scherbaum W. A., Bornstein S. R., Proc. Natl. Acad. Sci. U.S.A., 100, 14211-14216 (2003). 